\title{
Investigations on Presence of Biopolymer Producing Microorganism in Marine Soils \& Enhanced Potential of Marine Soill by Using Isolated Microorganism
}

\author{
Riya B. Thakkar ${ }^{1}{ }^{(\mathbb{D}}$, Krishna Shah ${ }^{2}{ }^{\mathbb{D}}$, Aditya Mehta ${ }^{2}{ }^{(\mathbb{D})}$, Manish V. Shah ${ }^{1}$, Shalini Singh ${ }^{1}{ }^{(\mathbb{D}}$, Tarun

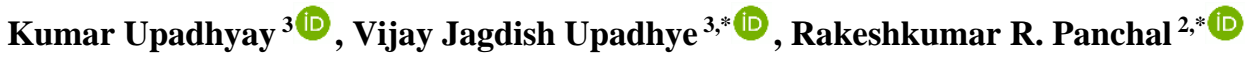

1 Department of Applied Mechanics, L.D. College of Engineering, Ahmedabad-380015, India; riyathakkar222@gmail.com (R.B.T.); mvs2212@yahoo.com.co.in (M.V.S.); shalini.2204@gmail.com (S.S.);

2 Department of Microbiology and Biotechnology, University School of Sciences, Gujarat University, Ahmedabad-380015 India; kintushah4534@gmail.com (K.S.); apmehta2812@gmail.com (A.M.); panchalrrce@ yahoo.com (R.R.P.);

3 Parul Institute of Applied Sciences \& Centre of Research for Development, Parul University, Vadodara, Gujrat, India391760; tarun_bioinfo@yahoo.co.in (T.K.U.); dr.vijaysemilo@gmail.com (V.J.U.);

* Correspondence:panchalrrce@yahoo.com(R.R.P);dr.vijaysemilo@gmail.com (V.J.U.);

Scopus Author ID 13103959700

Received: 7.05.2021; Revised: 20.06.2021; Accepted: 24.06.2021; Published: 8.08.2021

\begin{abstract}
Gujarat has a very extended coastal belt, and due to type, the properties of available soil in the coastal regions vary from place to place. These soil properties are not suitable for infrastructure development. Many techniques were already developed for the improvement of marine soil strength. Some of them are very costly; some method is not suitable due to high water table in the region. Some have adverse effects on aquatic life. This study has an approach to give sustainable, eco-friendly, and economical techniques to increase the unconfined compressive strength of marine soil of the different regions. The entire colonies available in soil are studied by series dilution and spread plate technique. Microorganisms produce exopolysaccharides (EPS) in excess carbohydrates, which provides by the screening method in nutrient agar broth (N. agar). Microbial Biopolymer such as exopolysaccharides can act as an eco-friendly binder of soil. EPS-producing organisms work as an environmentally sustainable method to improve soil strength. More exopolysaccharides-producing and fastest-growing microorganisms were selected by EPS extraction from all microorganisms found in a survey. The result was also compared with the unconfined compressive strength achieved by bio cement and a mixture of biopolymer and biocement. The biopolymer shows an increase in result (1.625-1.891) times from 14 days to 28 days. Biocement showed an increase in the result, which ranges from (1.763-1.955), and the mixture of both shows a tremendous increment of (1.635-1.885).
\end{abstract}

Keywords: marine soil microorganism; EPS; unconfined compressive strength; biopolymer.

(C) 2021 by the authors. This article is an open-access article distributed under the terms and conditions of the Creative Commons Attribution (CC BY) license (https://creativecommons.org/licenses/by/4.0/).

\section{Introduction}

Recent ongoing studies show that soil improvement has been considered due to population growth and land scarcity with appropriate ground conditions [1]. Numerous research reports highlight the methods to improve the geotechnical properties of soil. The methods of treating the soil with chemical and cement grout are widely used in geotechnical projects. But this method could damage aquatic life, affect the natural environment of soil, and contaminate groundwater flow [2]. To overcome this problem, the environmentally sustainable method is required. So, from the past 50 years, attempts have been made to improve soil 
properties and strength by microorganisms and biological processes present in the soil. Some potential microbiological method uses to improve soil properties are mineral precipitation (MICP), mineral transformation, biofilms, and biopolymers [3].Treat the soil with an alkaline activator or lime has a positive impact on soil strength.These are also eco-friendly materials [4]. Many experiments have been done to test the suitability and performance of soilbiopolymer interactions.Microorganisms-based polymers or Biopolymers have been introduced as an emerging tool for the construction binder, especially in the field of soil handling and enhancement.A newer and greater eco-pleasant method was evolved in few years known as microbial biopolymer, primarily based on soil treatment (BPST). BPST mostly increases the liquid limit (LL) of soils by improving pore fluid viscosity and soil wettability because of the biopolymers present inside the soil particles. However it decreases LL by an ionic bond between Montmorillonite and bacteria, which shows particle polymer aggregation [5]. Microbially induced calcium carbonate $\left(\mathrm{CaCO}_{3}\right)$ precipitation (biocalcification) is a very effective and successful method of improving the geotechnical properties of soil. The strength of soil also increases by this method. Utilizing the information of civil engineering, chemistry, and biology to improve soil strength [6,7]. MICP treatment uses the metabolic pathway of bacteria to form calcite, which binds the particle and increases soil strength [8]. The direct use of a biopolymer (natural polymer) in soil has benefits, such as lowering the time required for cultivation and excrement precipitation, which was very relevant to clayey soils [9].The polymeric material improved soil characteristics due to its desirable properties, low cost, and eco-friendly behavior [10]. Most microorganisms produce polysaccharides. They have an electrostatic charge on its surface, attracting the soil particles and binding them together. Due to this binding, soil aggregation can occur, and soil structure can change [11]. Biofilm has the capacity to interlink the porous media grains to the exopolysaccharide (EPS). These interparticle bridging exert a good effect on the mechanical conductivity of soils[12].The use of biopolymers, specifically EPS produced by microorganisms, has emerged as a technical opportunity for soil strength improvement, especially because of the exact soil pore filling known as the bio-clogging method[13]. These polymers are often related to the biofilm growth model. These functions include colonization and adhesion of the surfaces, support for biochemical interactions between the bacteria and environmental habitats, and protection of bacterial cells [14].The novel biopolymer has very high adhesive properties, which are able to bind plywood also. Such types of biopolymers are also used to bind the soil particles to increase their strength and reduce permeability [15]. Many bacteria produce a layer of polysaccharides or polyproteins with the help of plants which coat the soil particle's surface. They played an important role in cementing the sand, clay, and silt particles and converting microaggregates to improve soil strength. Biopolymers are biodegradable products. Due to this, they are used as a temporary support system in soil excavation.Biopolymers make gel into the soil, which increases liquefaction resistance and strengthens the soil. The CL-ML type soil is treated with three different types of biopolymer such as Xanthan gum, sodium alginate, and slime forming bacteria with a $2 \%$ dosage. The triaxial test measures the strength after the treatment.The shear strength was increased by about 50\% during the first week [6]. Some biopolymer such as Xanthan gum, Guar gum, Alginate, and chitosan can increase soil strength. biopolymer and soil connect to each other by electrostatic bond $[3,16]$. If the sand is treated with a minute amount of Xanthan Gum which will lead to improving the strength of sand. Increase the content of Xanthan Gum can increase the cohesion, but the angle of friction remains constant. Gellan Gum Can increase soil strength and soil durability by thermogelation treatment. Guar gum can 
increase soil strength. Agar can also affect the shear strength of soil due to the curing time effect. This all biopolymer tends to increase cohesion in soil, but the friction angle of treated soil decreases with time [17]. The optimum level of xanthan gum type biopolymer is 1 to 1.5 $\%$ for montmorillonite and kaolinite clay to improve strength and stiffness.It fills the soil pores [18]. Xantham gum has very less effect on the flexural strength of clay at very high water content.With water evaporation, the flexural strength of biopolymer treated clay increases compared to pure clay [19]. If the sand-clay mixture is treated with $2 \%$ guar gum. The unconfined compressive strength improved by 1.75 times, and hydraulic conductivity after 120 days of curing decreased by $2.72 \times 10^{5}$ times [20].An increase in guar gum content leads to an increment in the strength of the soil.This strength is due to hydrogen bond formation in soil.Hydrogen bonding is due to the chemical structure of guar gum [21]. Guar gum can also decrease the dry density of soil by a maximum extent. This biopolymer is also effective in collapsible soil [22]. It was already reported that many bacterial polysaccharides have either been adopted in the form of commercial products or have the potential for commercialization in the future [23]. Marine clay was treated with acrylamide (PAM) $2.0 \mathrm{~g} / \mathrm{kg}$ by the dry weight of the soil. Slurry of marine clay was prepared with $200 \%$ water content. The volume of the slurry was reduced by $29 \%$ within 2 hours. The unconfined compressive strength was increased by $360 \%$ and $135 \%$ for 14 and 28 days, respectively, compared to untreated clay [24]. Since soil is highly vulnerable to global change drivers such as climate and land-use intensification, changes in its content might result in important imbalances in the microbial diversity-tobiomass relationship $[25,26]$.

The physical properties of marine soil can be known by performing different field and laboratory testing. Physical parameters include soil classification, specific gravity, MDD, Atterberg limits, relative density, unconfined compression strength, permeability [27]. For laboratory tests, make uniform sand in three different grain sizes (D1, D2, D11). The sample of UCS was prepared at approximately $30 \%$ relative density. The axial load was increased continuously at a strain rate of $0.3 \%$ per $\min [28]$. The solution's $\mathrm{pH}$ was measured using a $\mathrm{pH}$ meter, and further, the electrical conductivity was determined by Cation exchange capacity (CEC). Sangmaneeet al. (2017) [29] described the chromic acid wet digestion method to measure the organic carbon content. Further, available nitrogen was determined by the alkaline permanganate method, which was explained by Chatterjee et al. (2020) [30], and available extractable Phosphorus by Bray Method as described by Sumithra et al. (2015) [31]. Extractable potassium from the soil with neutral $1 \mathrm{~N}$ ammonium acetate in the ratio of (1:5) and the potassium content in the extract was enumerated using a flame photometer [32]. The study conducted at Vishakhapatnam in India showed an increase in undrained strength around 20-100\%, undrained stiffness around 50-100\%, drained strength around 10-50 kPa.

Various tests are conducting on the sand to determining various parameters like density, particle size distribution, MDD, coefficient of curvature, coefficient of uniformity, relative density [33]. The soils which have a higher proportion of organic matter will act as a cementing agents. The X-ray diffraction test is performed to study the mineralogical composition of the soil sample. Then compare the observed X-ray pattern with standard JCPDS files to carry out the mineralogical analysis. The soil's X-ray diffraction pattern observes the presence of clay minerals, montmorillonites, chlorite, kaolinite, vermiculite, and quartz [34]. Heavy metals and other micronutrients are also present in the soil. Atomic absorption spectrometry (AAS) is performed to identify them for chemical analysis. The chemical environment affects the biological process of soil and its treatment [35]. Specific gravity and void ratio change linearly 
with a change in organic content. Water content, shear strength, Atterberg limit, friction angle change non-linearly with an increase in organic content [36]. The simple method for isolation is the serial dilution technique in which microorganisms can be cultured on an agar plate, and different developed colonies can be observed. A number of colonies then transfer to a single diluted plate for screening and identification. To identify microbes present in soil, the serial dilution method is used. All colony present in the soil is cultured, isolate and screening by a different method. The temperature of the site is measure at the time of sample collection. The microbes are cultivated at that temperature to get maximum growth $[37,38]$. The isolate colonies were identified or classify on the basis of temperature, $\mathrm{pH}$, different sugar utilization, hydrolysis test, protein utilization, and morphologic study [39]. Congo red agar test and tube test are used to check EPS and its capacity [40]. The initial pH of EPS was 6. The concentration of Media was determined by the orthogonal matrix method [41]. The EPS production has no correlation with the growth rate, and under nitrate depletion and the lowest PFD, the highest EPS was produced [42]. The negatively charged groups in EPSs bind cations and protect bacterial cells against toxic metals [43]. The different microorganisms produce chemically different binding agents, which are used for treatment in the soil. Different binding agents produced in the soil are based on diverse microorganisms' presence in soil [44].

\section{Materials and Methods}

\subsection{Marine soil.}

Marine soil was collected from six different places from Gujrat coastal region. The location of all places was shown in Figure 1 and coordinates in Table 1. The geotechnical test (such as grain size distribution, standard proctor test, hydrometer, Atterberg's limit) has been conducted as per the reported protocol of the Indian standard code. The geotechnical properties of all collected soil samples are presented in Table 2.

Table 1. Co-ordinates of different soil sample location.

\begin{tabular}{l|l} 
LOCATION & COORDINATES \\
\hline Harshad (District.- Dwarka) & $21.8351229,69.3651522$ \\
\hline Madhavpur (District - Porbandar) & $21.2794992,69.9356751$ \\
\hline Somnath (District - Gir somnath) & $20.884643,70.411433$ \\
\hline Chorvad (District - junagadh) & $20.9993053,70.2276781$ \\
\hline Khambhat & $22.2792778,72.6784259$ \\
\hline Bhavnagar & $21.679027,72.281405$
\end{tabular}

\subsection{Engineering properties and index of soil.}

Physiochemical properties of soil such as soil classification, Atterberg's limit, Standard proctor test, $\mathrm{pH}$, specific gravity were studied as per the reported Indian standard code in the laboratory.

\subsection{Isolation and screening of bacteria from soil.}

Bacteria were isolated from the soil samples by the serial dilution method. The isolation process was performed by taking $1 \mathrm{gm}$ of the soil sample and transferring it into $10 \mathrm{ml}$ of sterile distilled water to make a stock solution of 10 fold dilution. Further, an adequate aliquot of 1 $\mathrm{ml}$ from stock solution was transferred to $9 \mathrm{ml}$ of another sterile distilled water and shaken properly. These were further diluted serially to the sixth dilution. Spread plate method was 
adopted to enumerate bacterial isolates by inoculating a $0.1 \mathrm{ml}$ sample from $10^{-4}, 10^{-5}, 10^{-6}$ dilutions suspension tubes on Nutrient agar media with $4 \%$ sucrose as a carbon source and incubated for $48 \mathrm{~h}$. All these experiments were carried out in triplets. Isolates forming thick mucoid colonies were subsequently selected and purified by streaking four quadrants on a freshly prepared nutrient agar medium on a weekly basis to obtain pure and distinct colonies. Further, pure cultures were preserved by preparing a slant and stored at $4{ }^{\circ} \mathrm{C}$ for future experiments/investigations. Selected bacterial isolates were physically identified by their morphological and colony characteristics on agar medium. Also, a string test was performed and examined by Grams staining procedure.

\subsection{Selection and identification of EPS-producing bacteria.}

Exopolysaccharide-producing bacterial isolates were selected and identified by setting dry weight in an EPS broth and using sucrose as a carbon source. A cell suspension of $1.5 \times 10^{-}$ ${ }^{8}$ bacteria/ml of the overnight grown culture of each inoculum was prepared and further inoculated into $100 \mathrm{ml}$ EPS broth containing $4 \%$ sucrose as a carbon source, incubated in a rotary shaker at $30^{\circ} \mathrm{C}$ for $48 \mathrm{~h}$ at $120 \mathrm{rpm}$.

\subsection{EPS extraction/EPS recovery.}

After $48 \mathrm{hrs}$ of incubation, $25 \mathrm{ml}$ of the sample was withdrawn aseptically in a clean beaker. $\mathrm{pH}$, density, and viscosity were measured by the procedure described above manner. $25 \mathrm{ml}$ sample was centrifuged at 10,000 rpm for 10 minutes to remove cell biomass. The supernatant was transferred into a clean beaker, and refrigerated $15 \mathrm{ml}$ Chilled acetone was added into $5 \mathrm{ml}$ of sample, kept for overnight incubation at $4^{\circ} \mathrm{C}$. The next day formation of precipitate was observed. For constant weight, precipitates were taken into an aluminum foil and dried at $60^{\circ} \mathrm{C}$ for one night, and on the other day, weight at intervals of 30 minutes was taken. The weight of each isolate was observed, and an isolate with high EPS producing potential was selected for further study.

\subsection{EPS profiling.}

After $48 \mathrm{hrs}$ of incubation of EPS production, flask was observed for the foam production. A sterile $30 \mathrm{ml}$ sample was taken from the production flask into a clean beaker. The $\mathrm{pH}$, density, and viscosity were measured using a $\mathrm{pH}$ strip, $25 \mathrm{ml}$ graduated measuring cylinder, and size F Ostwald's viscometer.

\subsection{EPS characterization.}

Various methods were performed for characterization of EPS produced by different bacterial isolates, like string test after the extraction of EPS. Before putting at $60^{\circ} \mathrm{C}$ for overnight string test was performed. In semi-liquid form EPS taken on the aluminum foil was gently pulled by a nichrome wire loop and thread formation was observed and approx. length was measured using a graduated scale. For chemical characterization of EPS, carbohydrate estimation and protein estimation were performed. The total carbohydrate content of extracted EPS was determined by the DNSA (3,5 dinitro salicylic acid) method. The total protein content of extracted EPS was investigated by Folin-lowry's method with bovine serum albumin as a standard. 


\subsection{Specimen preparation.}

A specimen mold was made of a split polyvinyl chloride (PVC) pipe, $90 \mathrm{~mm}$ high and with an internal diameter of $45 \mathrm{~mm}$. The split PVC mold is stick by cellotaph for sample preparation. The oven-dry soil is used to prepare the sample. The soil was put in a room to cool down at room temperature. Selected Bacterial solution from EPS producing broth is added as per OMC in measured soil weight as per MDD. Bacterial solution was mixed uniformly in soil. The treated soil is filled in PVC mold as per IS Code. Sample for bio cement is also prepared by the same method. All samples remain at room temperature for 14 and 28 days.

\subsection{UCS Test.}

UCS tests were carried out for the determination of the compressive strength of the sample. The compressive strength characteristics of the specimens were studied by conventional laboratory testing method based on IS Code 2720 part 10 . The specimens were placed in a load frame driven at a constant strain of $0.20 \% / \mathrm{min}$ until failure occurred. Two specimens were used for each test, and the average result was taken. The samples were tested at 14 and 28 days. The results of UCS were compared with the UCS of biocement-treated samples and a mixture of biopolymer and biocement-treated samples.

\section{Results and Discussion}

\subsection{Index and engineering properties of soil.}

Table 2. Index and engineering properties of marine soil as per IS Code.

\begin{tabular}{l|l|l|l|l|l|l} 
& Bhavnagar & Chorwad & Harshad & Khambhat & Madhavpur & Somnath \\
\hline Liquid limit & $56.12 \%$ & - & - & $46.52 \%$ & - & - \\
\hline Plastic limit & $25.97 \%$ & - & - & $22.94 \%$ & - & - \\
\hline Plasticity index & $30.15 \%$ & - & - & $23.58 \%$ & - & - \\
\hline Hydrometer & $\begin{array}{l}\text { Clay }-45 \% \\
\text { Silt -50\% }\end{array}$ & - & - & $\begin{array}{l}\text { Clay - 30\% } \\
\text { Silt }-66 \%\end{array}$ & - & - \\
\hline $\begin{array}{l}\text { Soil } \\
\text { classification }\end{array}$ & $\begin{array}{l}\text { Highly plastic } \\
\text { clay (CH) }\end{array}$ & $\begin{array}{l}\text { Poorly } \\
\text { graded sand }\end{array}$ & $\begin{array}{l}\text { Poorly graded } \\
\text { sand }\end{array}$ & $\begin{array}{l}\text { Intermediate } \\
\text { plastic clay } \\
(\text { CI) }\end{array}$ & $\begin{array}{l}\text { Poorly graded } \\
\text { sand }\end{array}$ & $\begin{array}{l}\text { Well } \\
\text { graded sand }\end{array}$ \\
\hline Specific gravity & 2.656 & 2.71917 & 2.6924 & 2.74 & 2.6791 & 2.606 \\
\hline $\begin{array}{l}\text { Optimum } \\
\text { moisture content }\end{array}$ & $21.23 \%$ & $8.34 \%$ & $9.3 \%$ & $19.7 \%$ & $8.52 \%$ & $9.62 \%$ \\
\hline $\begin{array}{l}\text { Maximum dry } \\
\text { density }\end{array}$ & $1.628 \mathrm{gm} / \mathrm{cm}^{3}$ & $\begin{array}{l}1.694 \\
\mathrm{gm} / \mathrm{cm}^{3}\end{array}$ & $1.65 \mathrm{gm} / \mathrm{cm}^{3}$ & $1.668 \mathrm{gm} / \mathrm{cm}^{3}$ & $1.664 \mathrm{gm} / \mathrm{cm}^{3}$ & $\begin{array}{l}1.633 \\
\mathrm{gm}^{3} / \mathrm{cm}^{3}\end{array}$ \\
\hline pH & 7.5 & 8 & 7 & 6.7 & 7.6
\end{tabular}

\subsection{Total viable plate count.}

Three $N$. agar plates for every soil sample were put for 48 hours for the growth of colonies. The total colonies grow in agar plate is calculated by naked eyes.

Table 3. Total viable plate count from the actively cultured cells on N. agar plate.

\begin{tabular}{l|l|l|l|l|l|l} 
Plate No. & Somnath & Khambhat & Chorwad & Bhavnagar & Madhavpur & Harshad \\
\hline 1 & $4.2 \times 10^{5}$ & $2.5 \times 10^{5}$ & $8 \times 10^{5}$ & $1.53 \times 10^{6}$ & $1.65 \times 10^{6}$ & $6.37 \times 10^{6}$ \\
\hline 2 & $2.6 \times 10^{6}$ & $5.8 \times 10^{6}$ & $1.27 \times 10^{7}$ & $1.10 \times 10^{7}$ & $1.23 \times 10^{7}$ & $1.84 \times 10^{7}$ \\
\hline 3 & $2 \times 10^{7}$ & $4.5 \times 10^{7}$ & $3.5 \times 10^{7}$ & $6.5 \times 10^{7}$ & $1.52 \times 10^{8}$ & $9 \times 10^{7}$
\end{tabular}




\subsection{Primary screening.}

From the 6 soil samples total of 20 isolates were selected based upon their cultural characteristics. Bacterial isolates were grown on the N.agar plate. Large, round, uneven, mucoid, opaque, mostly pigment fewer colonies were observed on the nutrient agar plate.

Table 4. Slant grading of EPS-producing bacteria.

\begin{tabular}{l|l}
1 & $\mathrm{~S} 1>\mathrm{S} 2$ \\
\hline 2 & $\mathrm{~K} 1>\mathrm{K} 2$ \\
\hline 3 & $\mathrm{C} 1>\mathrm{C} 3>\mathrm{C} 2>\mathrm{C} 4$ \\
\hline 4 & $\mathrm{M} 1>\mathrm{M} 4>\mathrm{M} 3>\mathrm{M} 2$ \\
\hline 5 & $\mathrm{~B} 4>\mathrm{B} 2>\mathrm{B} 1>\mathrm{B} 3$ \\
\hline 6 & $\mathrm{H} 2>\mathrm{H} 3>\mathrm{H} 4>\mathrm{H} 1$
\end{tabular}

From selected 20 colonies, higher growth showing 6 colonies were selected based on slant grading for further studies from slant grading M1, H2, S2, B2, B4 was selected for detailed analysis. One outer strain W5 is also taken for study and compares the result with isolated bacteria from the soil as given in Table 5 .

Table 5. String test conducted on EPS Producing bacteria.

\begin{tabular}{l|l} 
Strain & Length $(\mathbf{c m})$ \\
\hline M1 & 2 \\
\hline H2 & 2.5 \\
\hline S2 & 1.5 \\
\hline B2 & 1 \\
\hline B4 & 1.5 \\
\hline W5 & 1
\end{tabular}

\subsection{Morphological characteristics.}

All selected 6 strains are separately cultured in an agar plate, and their morphological characteristics are studied by microscope. It shows that almost all strains show gram-negative reactions and motiles except B4, as shown in Table 6 and Figure 4.

Table 6. Morphological characteristic of selected strain under microscopic examination.

\begin{tabular}{l|l|l|l|l|l} 
Strain & Size & Shape & Arrangement & Gram's reaction & Motility \\
\hline M1 & Small & Thin rod & $\begin{array}{l}\text { Singly, short } \\
\text { chain }\end{array}$ & Negative & Motile \\
\hline H2 & Intermediate & Thin rod & Singly & Negative & Motile \\
\hline S2 & Big & Oval & $\begin{array}{l}\text { Singly, double, } \\
\text { clustered }\end{array}$ & Negative & Motile \\
\hline B2 & Small & Short rod & Singly, double & Negative & Motile \\
\hline B4 & intermediate & Thin rod & Singly & Positive & Non-motile \\
\hline W5 & Small & Short rod & Singly & Negative & Motile
\end{tabular}



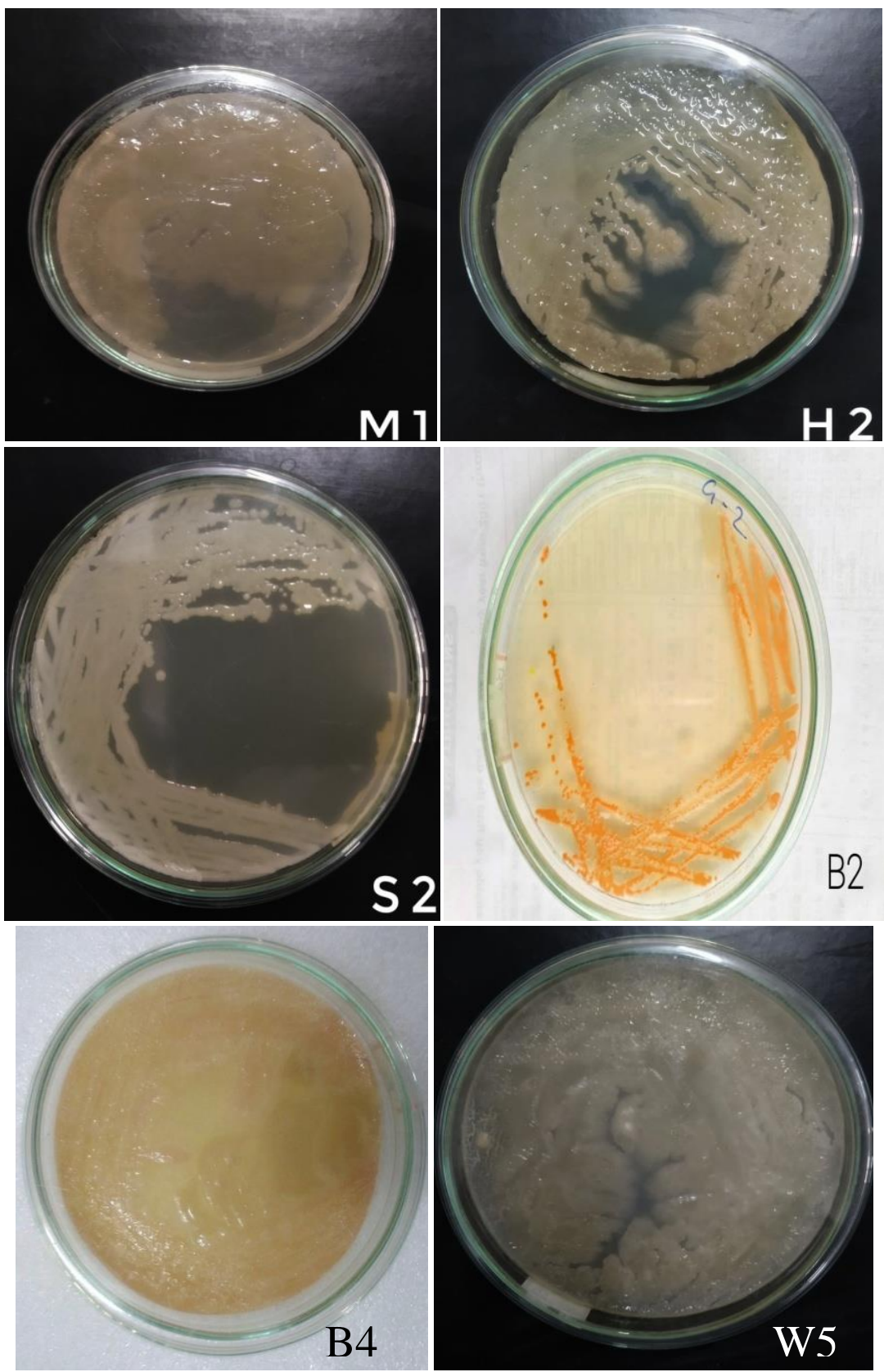

Figure1.Morphological features of the plate for respective strainsM1, B2, S2, W5, B4, H2 under microscopic examination.

\subsection{EPS profiling and recovery.}

For selecting the best broth for EPS producing bacteria, density and viscosity were studied for selected EPS broth and Nutrient broth strains.

Table 7. Density of the EPS broth and N. broth inoculated with selected EPS producing bacteria.

\begin{tabular}{l|l|l} 
Strain & $\begin{array}{l}\text { Density for EPS broth } \\
\mathbf{g m} / \mathbf{c m}^{\mathbf{3}}\end{array}$ & $\begin{array}{l}\text { Density for nutrient broth } \\
\mathbf{g m} / \mathbf{c m}^{\mathbf{3}}\end{array}$ \\
\hline With D.W. & 1 & 1 \\
\hline M1 & 1.027 & 1.008 \\
\hline H2 & 1.020 & 0.99 \\
\hline W5 & 1.008 & 1.028 \\
\hline B2 & 1.011 & 1.018 \\
\hline B4 & 1.001 & 1.032 \\
\hline S2 & 1.0322 & 0.964
\end{tabular}


Based on the density result, it was determined that the density is more for EPS broth than the nutrient broth. So, it's observed that EPS broth is more suitable to strain, as mentioned in Table 7. Viscosity was also measured for EPS broth and Nutrient broth inoculated with selected strain. The viscosity of EPS broth was higher than the viscosity of nutrient broth for all strains. From the result of viscosity, it is clear that EPS broth is good for the growth of EPSproducing strain, as mentioned in Table 8.

Table 8. Viscosity of the EPS broth and N. broth inoculated with the selected EPS-producing bacteria.

\begin{tabular}{l|l|l} 
Strain & $\begin{array}{l}\text { Viscosity of EPS broth } \\
\text { mPa.S }\end{array}$ & $\begin{array}{l}\text { Viscosity of nutrient broth } \\
\text { mPa.S }\end{array}$ \\
\hline D.W & 0.79 & 0.79 \\
\hline M1 & 1.25 & 0.83 \\
\hline B2 & 1.35 & 0.78 \\
\hline B4 & 0.99 & 0.76 \\
\hline W5 & 1.21 & 0.73 \\
\hline S2 & 1.02 & 0.69 \\
\hline H2 & 0.93 & 0.79
\end{tabular}

EPS recovery from EPS producing broth shows the weight of dry EPS in 5ml EPS broth. The higher the weight of EPS, The more production of EPS. From the result, it is observed that M1 and S2 showed maximum EPS recovery. So, for soil treatment M1 is selected for biopolymer treatment, and S2 was selected for Bio cementing treatment as given in Table 9.

Table 9. Gram \% of EPS produced by EPS producing bacteria in $5 \mathrm{ml}$ of the EPS broth.

\begin{tabular}{l|l} 
Strain & EPS recovery gram $\%$ \\
\hline M1 & 1.3 \\
\hline B2 & 0.4 \\
\hline B4 & 0.5 \\
\hline W5 & 0.6 \\
\hline S2 & 1.5 \\
\hline H2 & 0.9
\end{tabular}

3.7. Unconfined compression strength of marine soil.

3.7.1. UCS of Bhavnagar soil by biopolymer (M1), bio cement (S2) and mixture of both (M1 $+\mathrm{S} 2)$.



Figure 2. Unconfined compression strength of Bhavnagar soil for different strains and at different times. 
3.7.2. UCS of Chorvad soil by biopolymer (M1), bio cement (S2), and the mixture of both (M1 $+\mathrm{S} 2)$.

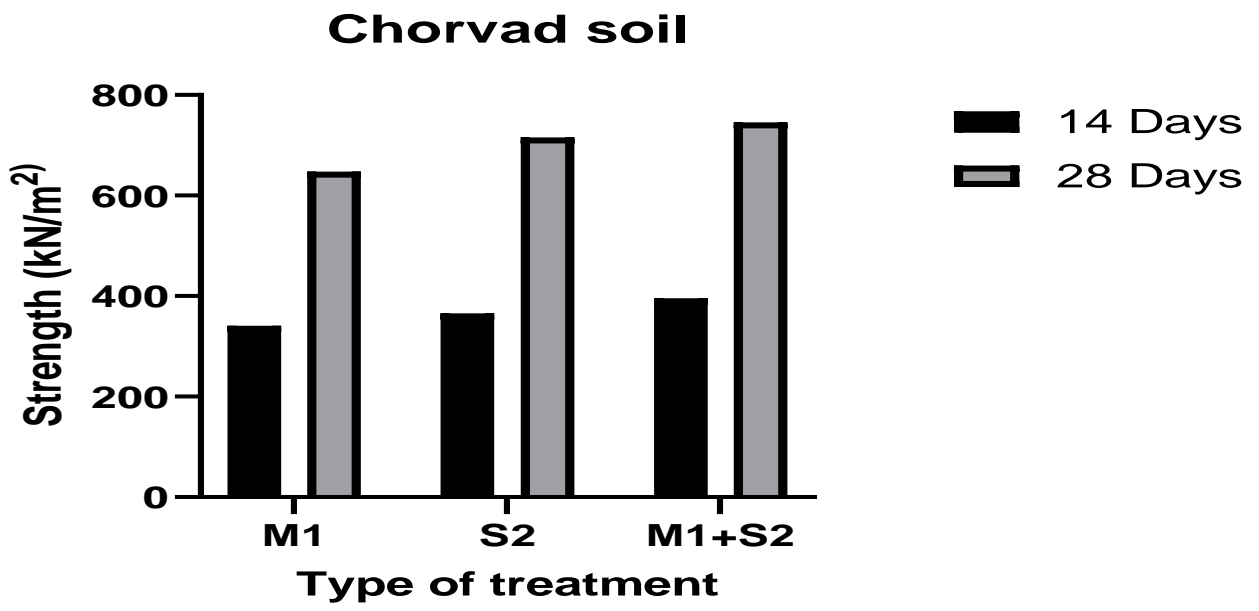

Figure 3. Unconfined compression strength of Chorvad soil for different strains and at different times.

3.7.3. UCS of Harshad soil by biopolymer (M1), bio cement (S2) and mixture of both (M1 + S2).

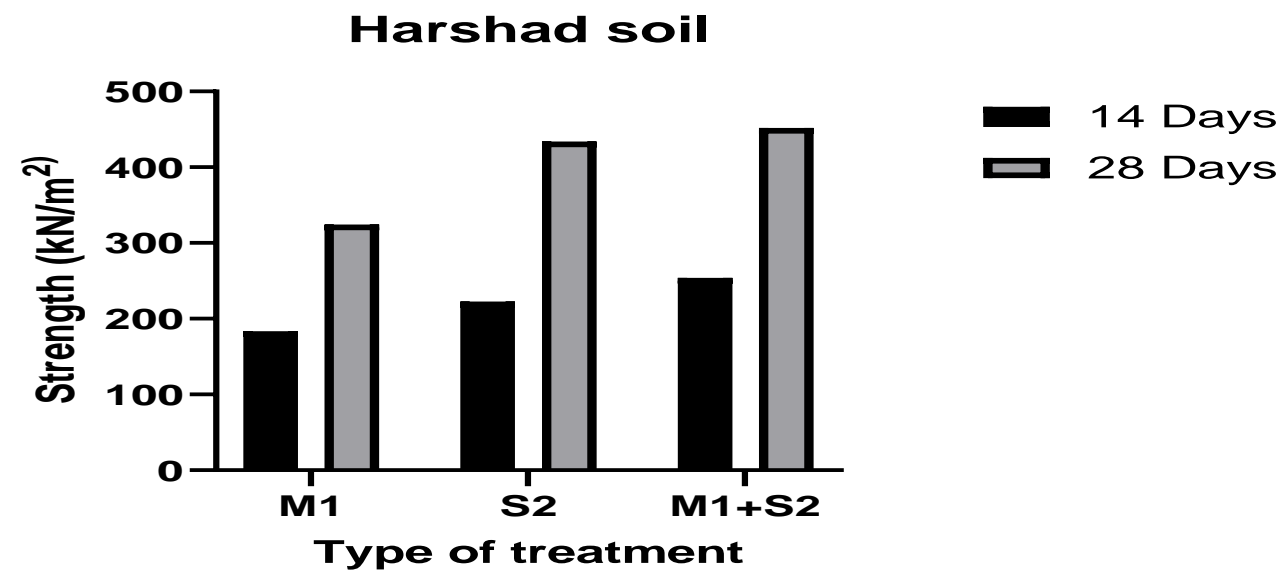

Figure 4. Unconfined compression strength of Harshad soil for different strains and at different times.

3.7.4. UCS of Khambhat soil by biopolymer (M1), bio cement (S2), and the mixture of both $(\mathrm{M} 1+\mathrm{S} 2)$.

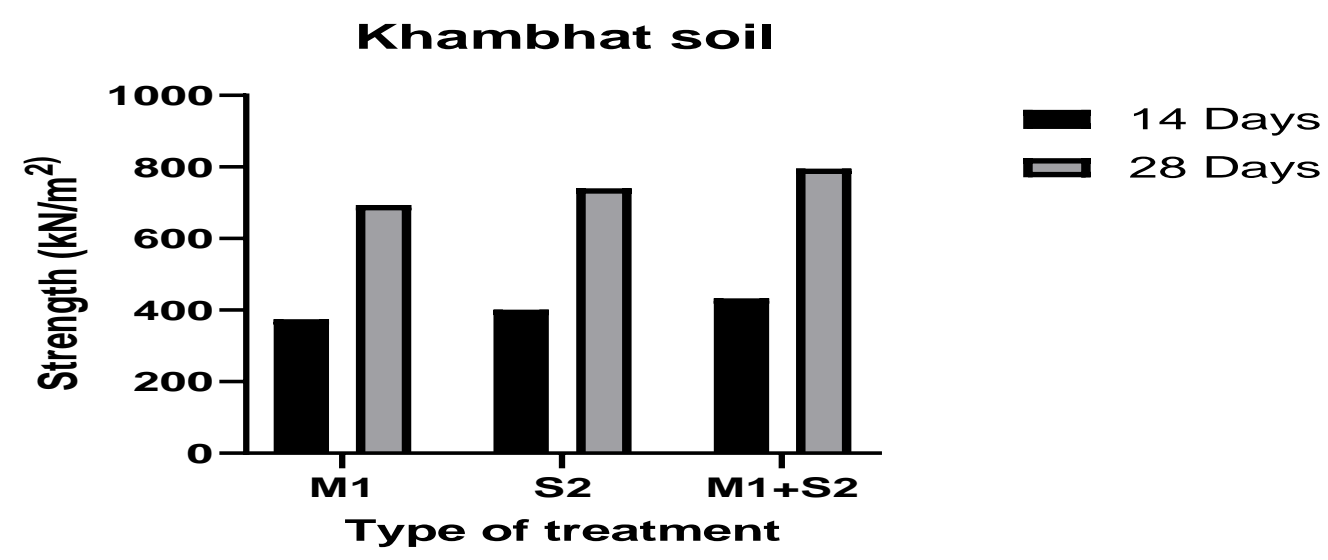

Figure 5. Unconfined compression strength of Khambhat soil for different strains and at different times. 
3.7.5. UCS of Madhavpur soil by biopolymer (M1), bio cement (S2), and the mixture of both $(\mathrm{M} 1+\mathrm{S} 2)$

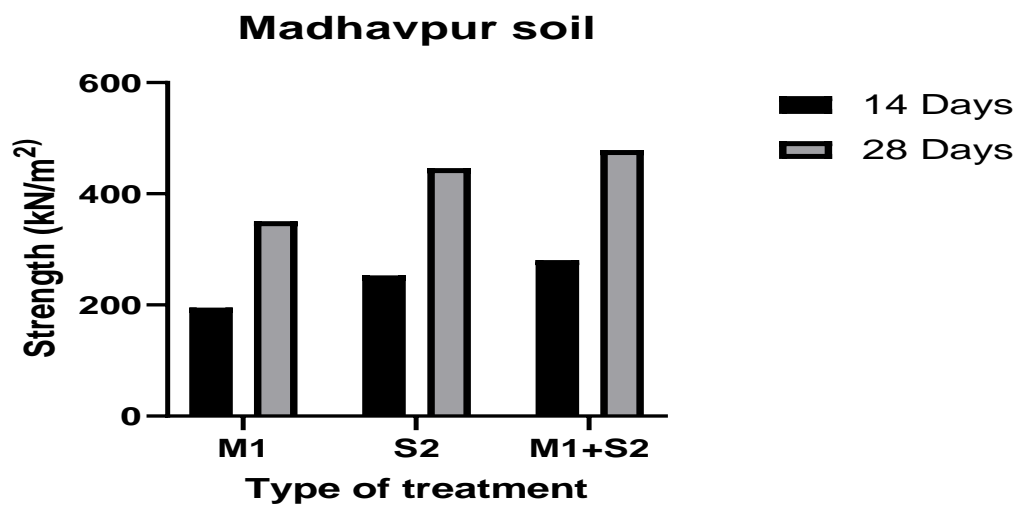

Figure 6. Unconfined compression strength of Madhavpur soil for different strains and at different times.

3.7.6. UCS of Somnath soil by biopolymer(M1), bio cement (S2) and the mixture of both(M1 $+\mathrm{S} 2$ ).

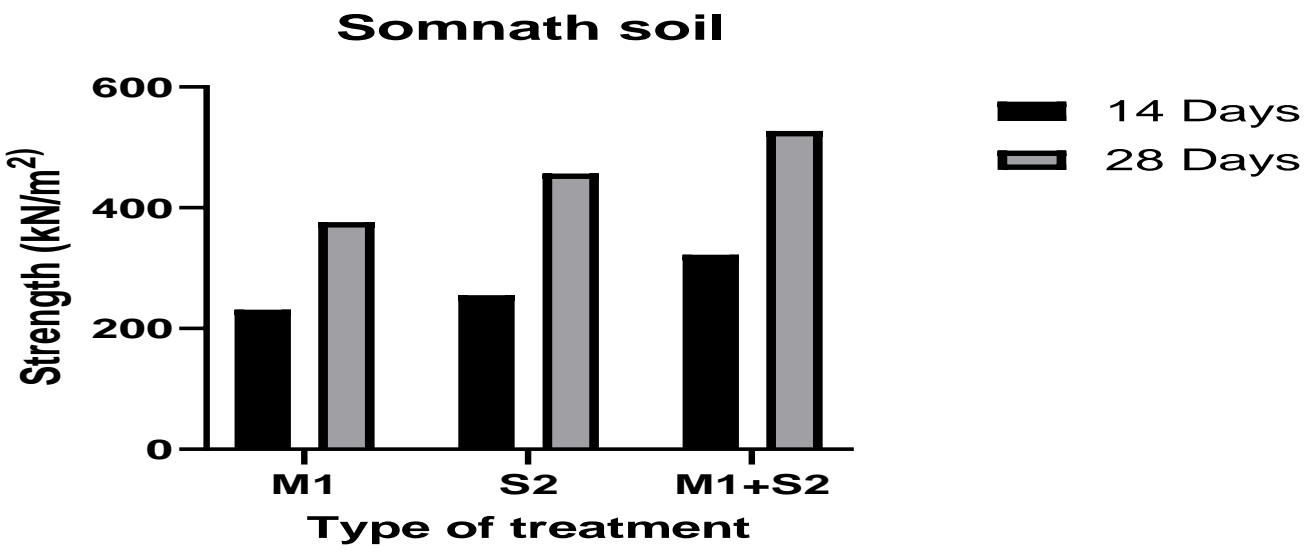

Figure 7. Unconfined compression strength of Somnath soil for different strains and at different time

\subsection{Discussion.}

A total of six marine soil samples were collected from the coastal region of Gujarat, India.The location was shown in Table 1. From six samples, three were poorly graded sand; others were well-graded sand, medium plastic clay, and high plastic clay. All other index properties results of soil were shown in Table 2. All soil has microbial diversity in nature. All soil samples were subjected to serial dilution method, and samples were spread on a nutrient agar plate for total bacteria count. The total viable count of all soil was shown in Table 3. Total viable bacteria on the nutrient agar plate were in the range of $2.5 \times 10^{5}$ to $1.52 \times 10^{8}$. From six soil, a total of 20 EPS producing strains was identified based on their cultural characteristic. Somnath and Khambhat soil were found with two EPS-producing strains. Harshad, Somnath, Madhavpur, and Khambhat soil were contained four EPS-producing strains. Most of the colonies observed in plates were round in shape, smooth, opaque, and have no pigments. All strains were transfer to slant for slant grading. From slant grading, six strains were selected for further analysis. The results of slant grading were represented in Table 4. Selected six strains were analyzed for string test, which results were in Table 5. M1 and S2 have shown good 
results as estimated by the string test. M1 shown $2 \mathrm{~cm}$ length, and $\mathrm{S} 2$ shown $2.5 \mathrm{~cm}$ length in string test. Table 6 showed the morphological characteristics of the selected strain, and Figure 4 shown a microscopy image of them. For the selection of broth, all six strains were transfer in nutrient broth and EPS broth. The density of M1 in EPS broth was $1.027 \mathrm{gm} / \mathrm{cm}^{3}$, and for S2, it was $1.0322 \mathrm{gm} / \mathrm{cm}^{3}$. From Table 7, it was observed that EPS broth was more suitable to strain than nutrient broth. The viscosity of M1and $\mathrm{S} 2$ was1.25 $\mathrm{mPa} . \mathrm{S}$ and $1.21 \mathrm{mPa} . \mathrm{S}$, respectively.Viscosity was higher for EPS broth as compare to nutrient broth shown in table 8 . EPS recovery of M1 and S2 were $1.3 \%$ and $1.5 \%$ in a $5 \mathrm{ml}$ solution of Eps broth. Table 9 shown the EPS recovery result of all six strains.Both had higher viscosity, density, and EPS recovery than other selected strains.M1 was insoluble in water, where S2 was soluble in water.M1 was selected for the biopolymer treatment of soil. S2 was selected for biocement treatment. For 14 days of treatment, UCS of biocement treated sand was (1.103- 1.296 times) higher than biopolymers, where UCS of the mixture of biopolymer and biocement treated sand was (1.255 -1.437 times) more than biopolymer treated sand. For clay, UCS was (1.071-1.074 times) more for biocement and (1.156-1.159 times) more for the mixture of biopolymer and biocement treatment than soil treated only with biopolymer. For 28 days treated marine soil, biocement treated sand shown (1.177-1.338 times) higher UCS and for the mixture of biopolymer and biocement treated sand (1.271-1.402 times) higher UCS than biopolymer treatment. For marine clay, UCS was (1.066-1.109 times) more for biocement and (1.145-1.153 times) more for the mixture of biopolymer and biocement treatment than soil treated with the only biopolymer. The result showed that unconfined compressive strength was highest for the mixture of biopolymer and biocement treated soil. Biopolymer treated soil shows the lowest strength. Increment of strength was higher for sand than the clay. From 14days to 28 days, The biopolymer illustrates the increase in result of UCS (1.625 - 1.891) times; biocement shows an increased result in range (1.763-1.955 times), and a mixture of both show the increment of (1.635-1.885 times). Bacteria responsible for producing biopolymer were insoluble in water, so there is less change in the water table on biopolymer. The bacteria were also isolated from the same marine soil, so they were habitant to live in that condition without any chances of biological contamination. There are a variety of microbes available in marine soil. There is diversity in microbes from place to place. The soil is poorly graded sand from Harshad (Devbhumi Dwarka) to Chorwad (Junagadh) costal line then at Bhavnagar and Khambhat coastal line it is Clay. Physical properties vary for different places. From all the isolated strains for EPS, M1 shows the best result for the production of biopolymer. S2 is selected for biocement treatment. The study shows that biopolymer is able to increase the unconfined compressive strength of marine soil. It can increase the strength of both marine sand and marine clay. It is also observed that it shows less result compared to biocement and mixture of biopolymer and biocement. The mixture of biopolymer and biocement can increase the maximum strength of marine soil. It was also found that the strength increases with time for all types of soil treatment. Based on these accomplishments, biopolymer can be proven an ecofriendly and environmentally sustainable technique for future improvement.

\section{Conclusions}

All type of soil shows increases in result with time. But the biocement requires continued nutrients for increased strength where there is no need to add any bipolymer ingredients after one treatment. Increasing strength with biopolymer is less than biocement, but it is cheaper than bio cement. The biopolymer shows the increase in result (1.625-1.891) times 
from 14 days to 28 days. Biocement shows an increase in range (1.763-1.955), and the mixture of both shows an increment of (1.635-1.885). The biopolymer can be work as a sustainable solution for the treatment of soil to increase strength. The bacteria are also isolated from the same marine soil, so their habitat is to live in that condition; therefore, there is no possible risk of any biological contamination. Biopolymer is an eco-friendly technique for ground improvement for the future.

\section{Funding}

This research received no external funding.

\section{Acknowledgments}

The authors thank the Department of Applied Mechanics, L.D. College of Engineering, Ahmedabad, and Centre of Research for Development (CR4D), Parul University, Vadodara Gujarat - for providing the facilities to carry out this study.

\section{Conflicts of Interest}

The authors declare no conflict of interest.

\section{References}

1. Maysam, B.; Hadi, F.; Ali, N.; Javad, H. Biological soil improvement using new environmental bacteria isolated from northern Iran. Environmental Geotechnics 2020, https://doi.org/10.1680/jenge.18.00176.

2. Mohapatra, S.S.; Pradhan, P.K. Review on Study of Soil Stabilization by Application of Microorganisms. In Recent Developments in Sustainable Infrastructure, Springer: 2021; 151-157, http://dx.doi.org/10.1007/978981-15-4577-1_12.

3. Soldo, A.; Miletić, M.; Auad, M.L. Biopolymers as a sustainable solution for the enhancement of soil mechanical properties. Sci. Rep. 2020, 10, 267, https://doi.org/10.1038/s41598-019-57135-x.

4. Kamaruddin, F.A.; Nahazanan, H.; Kim Huat, B.; Anggraini, V. Improvement of Marine Clay Soil Using Lime and Alkaline Activation Stabilized with Inclusion of Treated Coir Fibre. Applied Sciences 2020, 10, https://doi.org/10.3390/app10062129.

5. Chang, I.; Lee, M.; Tran, A.T.P.; Lee, S.; Kwon, Y.-M.; Im, J.; Cho, G.-C. Review on biopolymer-based soil treatment (BPST) technology in geotechnical engineering practices. Transportation Geotechnics 2020, 24, 100385, https://doi.org/10.1016/j.trgeo.2020.100385.

6. Whiffin, V.S.; van Paassen, L.A.; Harkes, M.P. Microbial Carbonate Precipitation as a Soil Improvement Technique. Geomicrobiol. J. 2007, 24, 417-423, https://doi.org/10.1080/01490450701436505.

7. Mitchell James, K.; Santamarina, J.C. Biological Considerations in Geotechnical Engineering. Journal of Geotechnical and Geoenvironmental Engineering 2005, 131, 1222-1233, https://doi.org/10.1061/(ASCE)1090-0241(2005)131:10(1222).

8. Mujah, D.; Shahin, M.A.; Cheng, L. State-of-the-Art Review of Biocementation by Microbially Induced Calcite Precipitation (MICP) for Soil Stabilization. Geomicrobiol. J. 2017, 34, 524-537, https://doi.org/10.1080/01490451.2016.1225866.

9. IChang, I.; Im, J.; Cho, G.-C. Introduction of Microbial Biopolymers in Soil Treatment for Future Environmentally-Friendly and Sustainable Geotechnical Engineering. Sustainability 2016, 8, http://dx.doi.org/10.3390/su8030251.

10. Selvakumar, S.; Soundara, B. 24 - Swelling behavior of expansive soils stabilized with expanded polystyrene geofoam inclusion. In New Materials in Civil Engineering, Samui, P., Kim, D., Iyer, N.R., Chaudhary, S., Eds. Butterworth-Heinemann: 2020,745-776, https://doi.org/10.1016/B978-0-12-818961-0.00024-7.

11. Manikandan, R.; Vijayakumar, R. Physico-Chemical Analysis of Marine Soils From Different Ecosystem Palk Strait Coastal Regions of Tamilnadu. India. J Marine Sci Res Dev 2016, 6, 2, http://dx.doi.org/10.4172/2155-9910.1000208.

12. Lin, H.; Suleiman, M.T.; Brown, D.G. Behavior of biofilm-treated sand. In IFCEE 2018, 2018; 1-11, https://doi.org/10.1061/9780784481592.001.

13. Mendonça, A.; Morais, P.V.; Pires, A.C.; Chung, A.P.; Oliveira, P.V. A Review on the Importance of Microbial Biopolymers Such as Xanthan Gum to Improve Soil Properties. Applied Sciences 2021, 11, https://dx.doi.org/10.3390/app11010170. 
14. Casillo, A.; Lanzetta, R.; Parrilli, M.; Corsaro, M.M. Exopolysaccharides from Marine and Marine Extremophilic Bacteria: Structures, Properties, Ecological Roles and Applications. Mar. Drugs 2018, 16, https://doi.org/10.3390/md16020069.

15. Chen, S.; Chen, Y.; Wang, Z.; Chen, H.; Fan, D. Renewable bio-based adhesive fabricated from a novel biopolymer and soy protein. RSC Advances 2021, 11, 11724-11731, https://doi.org/10.1039/D1RA00766A.

16. Kwon, Y.M.; Chang, I.; Lee, M.; Cho, G.C. Geotechnicalengineering behavior of biopolymer-treated soft marinesoil. Geomechanics and engineering, 2019,17, 453-464, https://doi.org/10.12989/gae.2019.17.5.453.

17. Jang, J. A Review of the Application of Biopolymers on Geotechnical Engineering and the Strengthening Mechanisms between Typical Biopolymers and Soils. Advances in Materials Science and Engineering 2020, 2020, 1465709, https://doi.org/10.1155/2020/1465709.

18. Adrienne McGinn, M.; Edwards, K.N.; Edwards, S. Chronic inflammatory pain alters alcohol-regulated frontocortical signaling and associations between alcohol drinking and thermal sensitivity. Neurobiology of Pain 2020, 8, 100052, https://doi.org/10.1061/(ASCE)MT.1943-5533.0001706.

19. Barani Omid, R.; Barfar, P. Effect of Xanthan Gum Biopolymer on Fracture Properties of Clay. J. Mater. Civ. Eng. 2021, 33, 04020426,https://doi.org/10.1061/(ASCE)MT.1943-5533.0003526.

20. Anandha Kumar, S.; Sujatha, E.R.; Pugazhendi, A.; Jamal, M.T. Guar gum-stabilized soil: a clean, sustainable and economic alternative liner material for landfills. Clean Technologies and Environmental Policy 2021, https://doi.org/10.1007/s10098-021-02032-z.

21. Sujatha, E.R.; Saisree, S. Geotechnical behaviour of guar gum-treated soil. Soils and Foundations 2019, 59, 2155-2166, https://doi.org/10.1016/j.sandf.2019.11.012.

22. Dehghan, H.; Tabarsa, A.; Latifi, N.; \& Bagheri, Y. Use of xanthan and guar gums in soil strengthening. Clean Technologies and Environmental Policy 2019, 21, 155-165, https://doi.org/10.1007/s10098-018-16250 .

23. Sutherland, I.W. Microbial polysaccharides from Gram-negative bacteria. Int. Dairy J. 2001, 11, 663-674, https://doi.org/10.1016/S0958-6946(01)00112-1.

24. Kou, H.-1.; Jia, H.; Chu, J.; Zheng, P.-g.; Liu, A.s. Effect of polymer on strength and permeability of marine clay. Marine Georesources \& Geotechnology 2021, 39, 234-240, https://doi.org/10.1080/1064119X.2019.1693669.

25. Bastida, F.; Eldridge, D.J.; García, C.; Kenny Png, G.; Bardgett, R.D.; Delgado-Baquerizo, M. Soil microbial diversity-biomass relationships are driven by soil carbon content across global biomes. The ISME Journal 2021, https://doi.org/10.1038/s41396-021-00906-0.

26. Lal, R. Soil Carbon Sequestration Impacts on Global Climate Change and Food Security. Science 2004, 304, 1623, https://doi.org/10.1126/science.1097396.

27. Yasodian, S.E.; Dutta, R.K.; Mathew, L.; Anima, T.M.; Seena, S.B.Effect of microorganism on engineering properties of cohesive soil.Geomechanics and Engineering, 2012, 4, 135-150, http://dx.doi.org/10.12989/gae.2012.4.2.135.

28. Kordnaeij, A.; Moayed, R.Z.; Soleimani, M. Unconfined compressive strength of loose sandy soils grouted with zeolite and cement. Soils and Foundations 2019, 59, 905-919, http://dx.doi.org/10.1016/j.sandf.2019.03.012.

29. Sangmanee, P.; Dell, B.; Harper, R.J.; Henry, D.J. Quantification of deep soil carbon by a wet digestion technique. Soil Research 2017, 55, 78-85, https://doi.org/10.1071/SR15297.

30. Chatterjee, A.; de Jesus, A.F.; Goyal, D.; Sigdel, S.; Cihacek, L.J.; Farmaha, B.S.; Jagadamma, S.; Sharma, L.; Long, D.S. Temperature Sensitivity of Nitrogen Dynamics of Agricultural Soils of the United States. Open Journal of Soil Science 2020, 10, 298-305, https://doi.org/10.4236/ojss.2020.107016.

31. Sumithra, P.; Viji, T.; Madhanraj, P.; Nadimuthu, N. Ecology and Biocontrol Potential of Soil Fungi of a Backwater Environment along the East Coast of India. Asian Journal of Pharmaceutical Research 2015, 5, 24-30, https://doi.org/10.5958/2231-5691.2015.00004.0.

32. Kalaivani, R.; Sukumaran, V.Characterization of bacterial diversity in marine sediment at different seasons in karankadu, Tamilnadu, india. International journal of pure and applied zoology 2013, 1, 97-108.

33. Owais, H.;Nasir, A.L.A Review Paper on Prediction of Relative Density of Sand. International Research Journal of Engineering and Technology (IRJET), 2020, 7, 4474-4476, https://www.irjet.net/archives/V7/i8/IRJET-V7I8767.

34. Basack, S.; Purkayastha, R.D.Engineering properties of marine clays from the eastern coast of India. Journal of Engineering and Technology Research, 2009, 1, 109-114.

35. Munirkumar, M.; Lav, K.; Ashutosh, M. Analysis of heavy metal in soil through atomic absorption spectroscopy for forensic consideration.International Journal for Research in Applied Science \& Engineering Technology, 2018, 6, https://www.ijraset.com/fileserve.php?FID=17992.

36. Gui, Y.; Zhang, Q.; Qin, X.; Wang, J. Influence of Organic Matter Content on Engineering Properties of Clays. Advances in Civil Engineering 2021, 2021, 6654121, https://doi.org/10.1155/2021/6654121.

37. Ben-David, A.; Davidson, C.E. Estimation method for serial dilution experiments. J. Microbiol. Methods 2014, 107, 214-221, https://doi.org/10.1016/j.mimet.2014.08.023. 
38. Jamil, N.; Ahmed, N. Production of biopolymers by Pseudomonas aeruginosa isolated from marine source. Brazilian archives of Biology and Technology 2008, 51, 457-464, http://dx.doi.org/10.1590/S151689132008000300004.

39. Sapkota, A.; Thapa, A.; Budhathoki, A.; Sainju, M.; Shrestha, P.; Aryal, S. Isolation, Characterization, and Screening of Antimicrobial-Producing Actinomycetes from Soil Samples. Int. J. Microbiol. 2020, 2020, 2716584, https://doi.org/10.1155/2020/2716584.

40. Saxena, N.; Maheshwari, D.; Dadhich, D.; Singh, S. Evaluation of Congo Red Agar for detection of biofilm production by various clinical Candida isolates. Journal of Evolution of Medical and Dental Sciences 2014, 3, 13234-13239, http://dx.doi.org/10.14260/jemds/2014/3761.

41. Kim, H.O.; Lim, J.M.; Joo, J.H.; Kim, S.W.; Hwang, H.J.; Choi, J.W.; Yun, J.W. Optimization of submerged culture condition for the production of mycelial biomass and exopolysaccharides by Agrocybe cylindracea. Bioresour. Technol. 2005, 96, 1175-1182,https://doi.org/10.1016/j.biortech.2004.09.021.

42. Silva, M.B.F.; Azero, E.G.; Teixeira, C.M.L.L.; Andrade, C.T. Influence of culture conditions on the production of extracellular polymeric substances (EPS) by Arthrospira platensis. Bioresources and Bioprocessing 2020, 7, 47, https://doi.org/10.1186/s40643-020-00337-3.

43. Nguyen, P.-T.; Nguyen, T.-T.; Bui, D.-C.; Hong, P.-T.; Hoang, Q.-K.; Nguyen, H.-T. Exopolysaccharide production by lactic acid bacteria: the manipulation of environmental stresses for industrial applications. AIMS microbiology 2020, 6, 451, http://dx.doi.org/10.3934/microbiol.2020027.

44. Aspiras, R.B.; Allen, O.N.; Harris, R.F.; Chesters, G. The role of microorganisms in the stabilization of soil aggregates. Soil Biol. Biochem. 1971, 3, 347-353, https://doi.org/10.1016/0038-0717(71)90045-9. 